\title{
PENERAPAN MODEL DISCOVERY LEARNING MENGGUNAKAN GAMBAR KARTUN MELALUI WHATSAPP DAPAT MENINGKATKAN HASIL BELAJAR SOSIOLOGI MATERI MASALAH SOSIAL
}

\author{
Oleh: \\ Anis Fauzi Nugroho ${ }^{1}$
}

\begin{abstract}
Abstrak
Minat dan kedisiplinan peserta didik yang kurang dibuktikan dengan presensi yang sering terlambat dan tidak mengikut pembelajaran serta kurang menanggapi tugas yang diberikan guru. Tujuan penelitian tindakan kelas ini adalah untuk meningkatkan hasil belajar sosiologi materi masalah sosial melalui gambar kartun. Subyek penelitian pada peserta didik kelas XI IPS 1 SMA Negeri 1 Watumalang Tahun Pelajaran 2020/2021. Siklus 1 dilaksanakan 2 pertemuan, sedangkan siklus 2 dilaksanakan 1 pertemuan dengan disertasi evaluasi di setiap pertemuan. Adanya penelitian tindakan kelas ini. Terjadi peningkatan hasil pembelajaran. Pada Pra siklus mayoritas siswa mendapatkan nilai rata-rata pengetahuan 50,8. Siklus I ratarata pengetahuan 78,4 dan Siklus II rata-rata pengetahuan 84, 68 .
\end{abstract}

Kata Kunci: Discovery Learning, Gambar kartun, Hasil Belajar

\footnotetext{
${ }^{1}$ Guru Sosiologi, SMA Negeri 1 Watumalang, e-mail: fauzisky77@gmail.com
} 


\section{PENDAHULUAN}

Pembelajaran jarak jauh merupakan pembelajaran yang diberikan kepada peserta didik yang tidak berkumpul bersama di satu tempat secara rutin untuk menerima pelajaran secara langsung dari guru mata pelajaran. Bahan-bahan dan instruksi-instruksi detail yang bersifat khusus dikirimkan atau disediakan untuk para peserta didik yang selanjutnya melaksanakan tugas-tugas yang akan dievaluasi oleh guru mata pelajaran. Dalam kenyataannya dapat dimungkinkan guru mata pelajaran dan peserta didik tersebut terpisah tidak hanya secara geografis namun juga waktu

Penyelenggaraan pembelajaran jarak jauh dengan basic online mendorong guru dan peserta didik untuk meningkatkan pengetahuan dan keterampilan dalam bidang teknologi informasi dan komunikasi. Hal ini menjadi alternatif solusi yang ditempuh selama pembelajaran tatap muka belum dapat dilaksanakan karena penyebaran virus corona masih terus meningkat. Penyelenggaraan pembelajaran jarak jauh tidak semudah dengan apa yang kita bayangkan. Harus ada cara yang terbaik dalam memberikan materi sehingga peserta didik tidak merasakan kebosanan. Misalnya pendidikan selama daring dengan metode konvensional seperti materi yang difoto lalu diminta untuk mempelajari materi tersebut. Lambat laun peserta didik menjadi bosan dan malas untuk belajar. Hal ini jauh sekali dari tujuan awal pendidikan yaitu mencerdaskan kehidupan bangsa.

Untuk itu, guru harus membuat inovasi dalam melakukan pembelajaran sehingga peserta didik tetap semangat dalam menjalankan pembelajaran daring selama COVID 19 dari rumah. Penyelenggaraan pembelajaran jarak jauh dengan basic online mendorong guru dan peserta didik untuk meningkatkan pengetahuan dan keterampilan dalam bidang teknologi informasi dan komunikasi. Hal ini menjadi alternatif solusi yang ditempuh selama pembelajaran tatap muka belum dapat dilaksanakan karena penyebaran virus corona masih terus meningkat.

Kendala yang sama juga dirasakan pada mata pelajaran sosiologi pada Pembelajaran Jarak Jauh ini. Minat dan kedisiplinan peserta didik yang kurang dibuktikan dengan presensi yang sering terlambat, bahkan tidak mengikuti. Kurang menanggapi tugas yang diberikan guru, pengumpulan tugas yang melebihi waktu tenggang, dan pengerjaan tugas yang terkesan tidak serius. Sehingga tujuan pembelajaran yang dilakukan tidak dapat terpenuhi

Atas dasar diatas peneliti memiliki rumusan masalah yaitu Apakah penerapan Model Discovery Learning menggunakan 
gambar kartun melalui WhatsApp dapat Meningkatkan Hasil Belajar Sosiologi materi Masalah Sosial pada peserta didik kelas XI IPS 1 SMA Negeri 1 Watumalang Tahun Pelajaran 2020/2021?

Tujuan penelitian tindakan kelas ini adalah untuk meningkatkan hasil belajar sosiologi materi masalah sosial pada peserta didik kelas XI IPS 1 SMA Negeri 1 Watumalang Tahun Pelajaran 2020/2021 dengan menggunakan model Discovery Learning dengan gambar kartun. Adapun dilakukannya penelitian tindakan kelas ini maka diharapkan membawa manfaat untuk berbagai pihak, yaitu meningkatkan ketertarikan peserta didik untuk mengikuti proses pembelajaran secara daring, memberikan kecakapan berfikir dan keberanian dalam menyampaikan pendapat pada saat proses pembelajaran sedang berlangsung, meningkatkan kualitas peserta didik dalam mata pelajaran sosiologi walaupun secara daring untuk peserta didik

\section{METODE PENELITIAN}

Bagian metode peneltian meliputi

\section{a. Subyek Penelitian}

Dalam melaksanakan penelitian ini penulis mengambil lokasi penelitian di SMA Negeri 1 Watumalang J1. Kyai Banjaran
Bedali Kecamatan Watumalang Kabupaten Wonosobo, Jawa Tengah. Alasan pemilihan kelas XI IPS 1 karena kelas ini memiliki nilai mata pelajaran Sosiologi yang paling rendah. Ini terlihat dari hasil Penilaian Harian 2 di semester gasal Tahun Pelajaran 2020 / 2021. Penelitian ini dilakukan mulai bulan Oktober 2020 sampai dengan November 2020. Dengan menggunakan model pembelajaran daring. Subyek penelitian adalah peserta didik kelas XI IPS 1 semester ganjil di SMA Negeri 1 Watumalang tahun pelajaran 2020/2021 yang terdiri dari 25 siswa.

\section{b. Teknik Pengumpulan Data}

Data dan sumber data yang akan dikumpulkan oleh peneliti adalah seluruh hasil pengamatan keadaan pembelajaran yang sebenarnya dan mengandung informasi terhadap kegiatan penelitian. Data serta sumber data dalam penelitian ini antara lain: Peserta didik kelas XI IPS 1 SMA Negeri 1 Watumalang. Data yang diperlukan berupa nilai ulangan atau tes sebelum dan sesudah penerapan model Discovery Learning. Tempat penelitian dilaksanakan di kelas XI IPS 1 SMA Negeri 1 Watumalang. Tahun Pelajaran 2020/2021

\section{c. Indikator keberhasilan}


1. Indikator keberhasilan proses, dilihat dari perkembangan proses pembelajaran. Analisis ini dilakukan dengan mendeskripsikan hal-hal yang terjadi selama proses tindakan kelas pada setiap siklusnya.

2. Indikator membandingkan hasil pembelajaran Program Linier Dua Variabel (PLDV) sebelum dan sesudah dilakukan tindakan pada tiap siklusnya dengan batas ketuntasan minimal (KKM) adalah 70. Selain itu, banyaknya peserta didik yang mendapat nilai kemampuan penalaran diatas KKM sebanyak lebih dari $80 \%$

\section{d. Tenik Analisis Data}

Teknik pengumpulan data yang akan digunakan dalam penelitian ini antara lain dengan menggunakan wawancara, observasi, dokumen dan dokumentasi sebagai teknik pengumpulan data. Serta menggunakan tes untuk mengetahui hasil belajar peserta didik terutama pada aspek kognitif. Teknik pengumpulan data tersebut akan dijelaskan sebagai berikut :

1. Wawancara

Wawancara adalah cara-cara memperoleh data dengan berhadapan langsung, bercakap-cakap, baik antara individu dengan individu maupun individu dengan kelompok. Namun saat ini karena pandemi COVID 19, wawancara dilakukan melalui aplikasi WA Group. Hal ini bertujuan agar data yang diperoleh peneliti lebih akurat dan lengkap.

2. Tes

Penggunaan tes bertujuan untuk mengukur hasil yang diperoleh peserta didik setelah pemberian tindakan. Tes tersebut dilaksanakan pada akhir siklus I dan siklus II untuk mengetahui hasil dari tindakan dari proses pembelajaran terhadap penguasaan materi masalah sosial

\section{Observasi}

Observasi merupakan salah satu teknik yang paling banyak dilakukan dalam penelitian, baik kuantitatif maupun kualitatif, baik sosial maupun humaniora. Observasi dalam penelitian ini dilaksanakan dengan menggunakan lembar observasi melalui WA group. Observasi pertama dilaksanakan oleh peneliti untuk memperoleh data mengenai perilaku peserta didik dan hasil belajar. Observasi kedua dilakukan setelah tindakan siklus pertama untuk mengetahui perkembangan hasil belajar dan observasi ketiga dilakukan setelah pelaksanaan tindakan siklus II yang bertujuan untuk mengetahui hasil akhir dan meningkat atau tidaknya perolehan hasil belajar peserta didik.

3. Dokumen

Kajian dokumen tersebut meliputi kurikulum, silabus, RPP, materi pembelajaran sosiologi dengan penerapan model Discovery Learning

4. Dokumentasi 
Dokumentasi yang diambil peneliti bertujuan untuk memperkuat hasil yang sudah ada, dibuktikan dengan foto kegiatan setiap pertemuan baik siklus I maupun siklus II.

\section{a. Pra Siklus}

Sebelum melakukan penelitian tindakan kelas, peneliti terlebih dahulu mengadakan observasi awal kegiatan pembelajaran dilakukan pada awal bulan Oktober 2020. Selama observasi, peneliti mengamati proses pembelajaran sosiologi di SMA Negeri 1 Watumalang. Dari hasil observasi yang dilakukan peneliti, pembelajaran sosiologi dilaksanakan secara daring di SMA Negeri 1 Watumalang.
Pembelajaran yang selama ini dilakukan menggunakan WA Group namun pembelajaran hanya sebatas membagikan materi dan latihan soal. Semua kegiatan peserta didik dilakukan secara individual.

Hal ini menyebabkan peserta didik pasif, kurang melatih keterampilan berpendapat, interakasi antara guru dan peserta didik kurang, interaksi antar peserta didik kurang sehingga menyebabkan tingkat pemahaman peserta didik terhadap materi rendah sehingga terjadi penurunan hasil belajar. Perlu kita ketahui bersama, hasil belajar dalam kondisi pandemi ini menurun jika dibandingkan dengan kondisi sebelum pandemi.

\begin{tabular}{|l|l|l|}
\hline Keterangan & $\begin{array}{l}\text { PTS 2 Tahun Pelajaran } \\
\text { Tatap muka }\end{array}$ & $\begin{array}{l}\text { PTS 1 Tahun Pelajaran } \\
\text { PJJ }\end{array}$ \\
\hline Nilai PTS & 76 & 55 \\
\hline
\end{tabular}

Dari observasi yang telah dilakukan maka dapat disimpulkan bahwa pembelajaran daring yang selama ini dilaksanakan belum memberi kesempatan kepada peserta didik untuk aktif dalam kegiatan belajar mengajar sehingga kompetensi dan kemampuan berfikir kurang maksimal pada proses pembelajaran. Sehingga hasil hasil belajar belum maksimal. Hal ini dibuktikan dengan penurunan hasil belajar penilaian tengah semester pada saat pandemi, dibandingkan dengan penilaian akhir semester pada saat pembelajaran luring Rata-rata hasil Pra siklus 50,8 


\begin{tabular}{|c|c|c|c|}
\hline \multicolumn{4}{|c|}{$\begin{array}{l}\text { PENILAIAN PENGETAHUAN } \\
\text { MATA PELAJARAN SOSIOLOGI } \\
\text { KELAS XI IPS } 1\end{array}$} \\
\hline \multirow{2}{*}{ No } & \multirow{2}{*}{ No. Induk } & \multirow{2}{*}{ Nama } & PENILAIAN \\
\hline & & & SIKLUS 1 \\
\hline 1 & 3612 & ADITHYA HERAWAN ANDREANSYAH & 80 \\
\hline 2 & 3711 & AFITA RAHAYU & 85 \\
\hline 3 & 3613 & AHMAD RUDIANAM & 75 \\
\hline 4 & 3614 & ALDI MA'RUF AMIN & 75 \\
\hline 5 & 3615 & ALIMMA ZAHRA & 80 \\
\hline 6 & 3617 & ASIH DEFVINA & 80 \\
\hline 7 & 3618 & BACHTIAR NUGROHO & 75 \\
\hline 8 & 3713 & DICKY OCTAVIAN & 80 \\
\hline 9 & 3708 & DWI NURLAELI & 75 \\
\hline 10 & 3619 & EKO WIJIYANTO & 80 \\
\hline 11 & 3620 & ELY FITRIYANTI & 85 \\
\hline 12 & 3621 & FEBRY DWI SANTOSO & 75 \\
\hline 13 & 3622 & FIKA RISTIANING HIDAYAT & 85 \\
\hline 14 & 3706 & HENDRI CAHYA PRATAMA & 75 \\
\hline 15 & 3623 & HENI SETYO NINGSIH & 80 \\
\hline 16 & 3624 & ILHAM FAKHRIDHO & 75 \\
\hline 17 & 3625 & LAILA FATUR ROHMANIYAH & 85 \\
\hline 18 & 3626 & LUHUR FAMBUDI & 80 \\
\hline 19 & 3627 & MAFTU NUR FAISAH & 75 \\
\hline 20 & 3628 & MIEA PUTRI ARDIKA & 70 \\
\hline 21 & 3629 & MUHAMAD LUTVI KARIM & 75 \\
\hline 22 & 3630 & NABILA DAMAYANTI & 85 \\
\hline 23 & 3631 & NANDA AFRIZAL RAMADHANI & 80 \\
\hline 24 & 3632 & NOVITA DWI WAHYUNI & 80 \\
\hline 25 & 3633 & NURUL HUDA & 70 \\
\hline & & RATA -RATA & 78.4 \\
\hline
\end{tabular}

\section{b. Siklus I}

Pelaksanaan siklus I dilaksanakan dalam satu kalitindakan. Pelaksanaan dilakukan pada Kamis 23 Oktober 2020. Adapun perencanaan, pelaksanaan dan refleksi dari pelaksanaan tindakan adalah sebagai berikut: Peneliti menjelaskan materi mengenai faktor penyebab masalah sosial melalui materi WA Group. Dalam penjelasan materi tersebut peneliti masih menggunakan media pembelajarn power point presentation yang disertai gambar sebagai ilustrasi. Di sela-sela penyajian materi peneliti membuka komuniasi dengan peserta didik dengan pertanyaanpertanyaan yang berkaitan dengan materi, hal ini bertujuan untuk merangsang keaktifan peserta didik dalam pembelajaran. Setelah penjelasan materi selesai peneliti memberikan kesempatan kepada siswa untuk bertanya. Karena Kompentensi dasar yang dibahas dalam penelitian ini adalah mengenai masalah sosial sehingga dirasa sangat cocok untuk metode Discovery Learning. Dalam tindakan pertama ini permasalahan 
ditentukan oleh peneliti. Masalah yang disajikan untuk peserta didik diambil dari link youtube yang berkaitan dengan materi masalah sosial yaitu masalah kemiskinan, kriminalitas, kesenjangan sosial, ketidakadilan, kenakalan remaja dan yang terbaru yaitu covid-19. Pelaksanaan Discovery Learning pada tindakan pertama ini dilaksanakan secara individual.

\section{c. Siklus II}

Pelaksanaan siklus II dilaksanakan dalam satu kali tindakan. Pelaksanaan dilakukan pada Kamis 4 November 2020. Adapun perencanaan, pelaksanaan dan refleksi dari pelaksanaan tindakan Sesuai dengan rencana yang telah dibuat, kegiatan pembelajaran dilaksanakan dengan metode pembelajaran Discovery Learning dengan menggunakan platform googleclasroom yang di padukan dengan googlemeet dan google formulir. Pembelajaran dengan diawali peneliti membagikan materi secara asinkronus sehari sebelumnya. Dengan memperhatikan refleksi dari siklus 1 , maka siklus ke II peneliti memperbaiki proses pembelajaran. Diantaranya adalah memperbaiki layout bahan ajar agar lebih menarik, membuat media power point agar peserta didik lebih tertarik pada materi, dan menggunakan googlemeet untuk presentasi peserta didik mengungkapkan gagasannya. Pada siklus ke II ini materi disampaikan melalui modul dengan perbaikan pada layout dan materi disampaikan melalui power point disertai penjelasan dari guru. Hal ini bertujuan agar peserta didik lebih tertarik pada penyampain materi sehingga dapat tersanpaikan dengan baik.

Pada siklus II ini metode Discovery Learning dilakukan secara berkelompok. Hal ini bertujuan untuk memberi kesempatan kepada peserta didik untuk berdiskusi. Pada siklus ini peserta didik berdiskusi untuk mengangkat permasalahan sosial yang terjadi dilingkungan tempat tinggalnya. Kemudian dirumuskan alternatif penyelesaian masalah. Pada siklus ini hasil penyelesaian masalah mengalami peningkatan yang signifikan, Penyelesaian masalah sudah lebih mendetail dibandingkan dengan siklus 1 . Penilaian pada tindakan kedua yaitu penugasan di classroom dengan pengerjaan kelompok dan google formulir. Tugas ini hanya sebagai latihan untuk siswa. Dapat dilihat dari tabel hasil belajar di bawah ini. Rata -rata meningktat menjadi 85,2 


\section{PENILAIAN PENGETAHUAN \\ MATA PELAJARAN SOSIOLOGI \\ KELAS XI IPS 1}

\begin{tabular}{|c|c|c|c|}
\hline No & No. Induk & Nama & PENILAIAN \\
\hline & & & SIKLUS 2 \\
\hline 1 & 3612 & $\begin{array}{ll}\text { ADITHYA } & \text { HERAWAN } \\
\text { ANDREANSYAH } & \\
\end{array}$ & 85 \\
\hline 2 & 3711 & AFITA RAHAYU & 90 \\
\hline 3 & 3613 & AHMAD RUDIANAM & 80 \\
\hline 4 & 3614 & ALDI MA'RUF AMIN & 82 \\
\hline 5 & 3615 & ALIMMA ZAHRA & 84 \\
\hline 6 & 3617 & ASIH DEFVINA & 86 \\
\hline 7 & 3618 & BACHTIAR NUGROHO & 80 \\
\hline 8 & 3713 & DICKY OCTAVIAN & 84 \\
\hline 9 & 3708 & DWI NURLAELI & 86 \\
\hline 10 & 3619 & EKO WIJIYANTO & 84 \\
\hline 11 & 3620 & ELY FITRIYANTI & 88 \\
\hline 12 & 3621 & FEBRY DWI SANTOSO & 80 \\
\hline 13 & 3622 & FIKA RISTIANING HIDAYAT & 90 \\
\hline 14 & 3706 & HENDRI CAHYA PRATAMA & 82 \\
\hline 15 & 3623 & HENI SETYO NINGSIH & 88 \\
\hline 16 & 3624 & ILHAM FAKHRIDHO & 85 \\
\hline 17 & 3625 & LAILA FATUR ROHMANIYAH & 87 \\
\hline 18 & 3626 & LUHUR FAMBUDI & 84 \\
\hline 19 & 3627 & MAFTU NUR FAISAH & 80 \\
\hline 20 & 3628 & MIEA PUTRI ARDIKA & 88 \\
\hline 21 & 3629 & MUHAMAD LUTVI KARIM & 80 \\
\hline 22 & 3630 & NABILA DAMAYANTI & 88 \\
\hline 23 & 3631 & NANDA AFRIZAL RAMADHANI & 86 \\
\hline 24 & 3632 & NOVITA DWI WAHYUNI & 90 \\
\hline 25 & 3633 & NURUL HUDA & 80 \\
\hline & & RATA -RATA & 84.68 \\
\hline
\end{tabular}

\section{HASIL}

Pencapaian Nilai Pada metode

Discovery learning menggunakan gambar kartun 


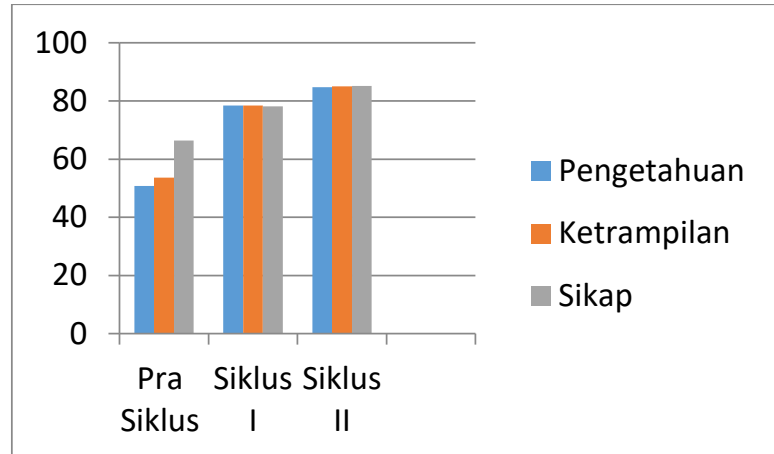

Nilai pengetahuan yang tercapai diharapkan juga menambah pengetahuan selama melakukan penelitian tindakan dan kemampuan peserta didik dalam kelas ini adalah Pra siklus rata-rata 50, 8. menganalisis permasalah sosial di Siklus I rata-rata 78, 4 dan Siklus II ratamasyarakat pada umumnya. Namun masih rata 84.68. Penggunaan gambar kartun terdapat kekurangan dari pelaksanaan memberikan dampak positif pada peserta Penelitian Tindakan kelas ini antara lain didik disebabkan banyak nya peserta didik Waktu penelitian tindakan kelas dilakukan yang menyukai film kartun dan mereka masih bisa menerangkan jalan cerita yang terjadi walaupun sudah menonton kemarin yang terbatas dan Kendala teknis pada gadged dan sinyal yang digunakan untuk sore. Adanya pembelajaran gambar kartun mengikuti pembelajaran daring 


\section{Daftar Pustaka}

Basuki, H., Siti, R. \& Moharromiyati. (2009). Sosiologi. Surakarta: FKIP UNS Surakarta

Bambang, Warsita. (2008). Teknologi Pembelajaran. Jakarta: Rineka Cipta

Iskandar. (2012). Penelitian Tindakan Kelas. Jakarta Selatan: GP Press Group

Martinis, Yamin. (2013). Paradigma Baru Pembelajaran. Jakarta: Referensi

Muhammad, T. \& Arif, M. (2013). Belajar dan Pembelajaran. Yogyakarta: Ar-Ruzz Media

Mulyasa. (2013). Pengembangan dan Implementasi Kurikulum 2013. Bandung : Remaja Rosdakarya

J Jefri, J Junaidi - Penerapan Model Talking Stick Untuk Meningkatkan Partisipasi Belajar Siswa Pada Pembelajaran Sosiologi Kelas $\quad X \quad I P S \quad 1 \quad$ SMA Negeri 3 Bukittinggi 2019.Jurnal Perspektif, 2019 - perspektif.ppj.unp.ac.id

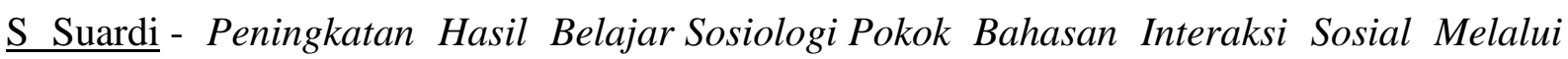
Metode Diskusi pada Siswa Kelas X MA. Muhammadiyah Panaikang.JED (Journal of Etika Demokrasi), 2017 - journal.unismuh.ac.id

D Watri-Penggunaan Vcd Dalam Pembelajaran Sosiologi Dalam Upaya Meningkatkan Minat Belajar. Jurnal Inovasi Pembelajaran Karakter, 2020 - i-rpp.com 